\title{
URBANA GEOGRAFIJA: GEOGRAFSKE ZNAČILNOSTI MEST IN URBANIZACIJE V SVETU
}

\author{
Dejan Rebernik: Urbana geografija: geografske značilnosti mest in urbanizacije \\ v svetu. Razprave Filozofske fakultete, 294 str. Znanstvenoraziskovalni inštitut \\ Filozofske fakultete, Ljubljana 2008.
}

V letu 2008 je pri Znanstvenoraziskovalnem inštitutu Filozofske fakultete v zbirki Razprave izšlo delo Dejana Rebernika z naslovom Urbana geografija: geografske značilnosti mest in urbanizacije $v$ svetu. Čeprav je urbana geografija v zadnjem obdobju doživela hiter razvoj in čeprav so tudi sodobna mesta doživela velike spremembe, je minilo skoraj četrt stoletja, odkar je v Sloveniji izšlo podobno zastavljeno knjižno delo, katerega avtor je bil Igor Vrišer. To vrzel na področju geografske obravnave mest je zdaj zapolnila knjiga Dejana Rebernika. Gre za obsežno delo, v katerem so predstavljeni različni vidiki urbane geografije oziroma urbanizacije v svetu. Knjigo odlikujejo tudi bogato in raznovrstno slikovno gradivo ter množica aktualnih podatkov.

V uvodnem delu avtor predstavi urbano geografijo kot geografsko disciplino, ki preučuje mesto kot celovit prostorski pojav. Oriše njene začetke in razvoj ter njene bistvene značilnosti v sedanjem času. Ustavi se tudi pri različnih pristopih v urbani geografiji, npr. neoklasičnem ekonomskem pristopu, behaviorizmu, strukturalizmu in drugih. Prav tako se ni mogel izogniti opredelitvi mesta, ki je predmet preučevanja urbane geografije. Pri tem predstavi prakso iz različnih držav po svetu, posebej pa se posveti tudi opredelitvi mest v Sloveniji.

V nadaljevanju sta predstavljena nastanek in razvoj mest od zgodnjih urbanih civilizacij starega veka (npr. v Mezopotamiji, na območju stare Grčije in v obdobju rimskega cesarstva), prek srednjega veka, obdobja renesanse in baroka, dobe industrializacije do današnjega časa. Pozornost je namenjena tako kronološkemu razvoju in glavnim vplivnim dejavnikom kot tudi prostorski strukturi mest in oblikovanju urbanega sistema. V poglavju so grafično predstavljeni tudi številni konkretni primeri mest iz različnih obdobij.

Četrto poglavje je namenjeno različnim vidikom sodobne urbanizacije. Tako je posebej obravnavana suburbanizacija - dejavniki, ki so vplivali nanjo in različne pojavne oblike. Posebna podpoglavja so namenjena tudi pojavom periurbanizacije, eksurbanizacije, counterurbanizacije, razpršene urbanizacije in reurbanizacije. Pri tem so predstavljene osnovne značilnosti teh pojavov, opozorjeno pa je tudi na dileme, povezane z njihovo opredelitvijo in razumevanjem. Predstavljen je tudi model urbanizacijskega cikla, ki opisuje potek urbanizacije in njeno preobrazbo. Seveda ne gre brez podrobnejše predstavitve sodobnih urbanizacijskih procesov v Sloveniji. Pozornost je namenjena tako ugotovitvam avtorjev, ki so o tem pisali v preteklosti, kot tudi najnovejšim dogajanjem in procesom, pa tudi možnim scenarijem prihodnjega urbanega razvoja.

$\mathrm{V}$ naslednjem poglavju se avtor ukvarja $\mathrm{z}$ mesti in urbanizacijo $\mathrm{v}$ svetu ter dejavniki, ki so vplivali na razlike med različnimi območji. Poglavje je zaključeno s predstavitvijo najpomembnejših urbanizacijskih trendov v svetu.

$\mathrm{V}$ šestem poglavju avtor obravnava urbane sisteme in njihove tri osnovne dimenzije: hierarhično oziroma vertikalno, prostorsko oziroma horizontalno in časovno oziroma zgo- 
dovinsko. V okviru tega so predstavljeni tudi pravilo velikosti mest, zakon primarnega mesta in Christallerjeva teorija o centralnih naseljih. Spet je posebna pozornost namenjena urbanim sistemom v Sloveniji oziroma njihovim osnovnim značilnostim.

Naslov sedmega poglavja je Mesto in okolica-mestne regije. V njem se avtor posveti tudi vprašanju opredelitve mestnih regij. Pri tem obravnava različne kriterije, ki se uporabljajo, ter različne primere opredeljevanja mestnih regij po svetu. Obravnavana je tudi prostorska struktura mestnih regij.

Osmo poglavje se ukvarja z mestno zgradbo. V okviru tega so predstavljeni različni primeri mestne zgradbe - od klasičnih (ekoloških) modelov prek ekonomskih (neoklasičnih) modelov do politično-ekonomskega (strukturalističnega) modela mestne zgradbe. Avtor se posebej ustavi tudi pri pojmu postmoderno mesto, ki se je uveljavil za opis tipa mesta, kakršen se je oblikoval ob koncu 20. stoletja.

Sledi obravnava morfološke zgradbe mesta. Kot omeni avtor na začetku poglavja, je morfološka zgradba vidno zaznavni element mestne zgradbe in odraža značilnosti mestne pokrajine. Obravnavani so različni relevantni pojmi, npr. morfološki elementi, način zazidave in mestni tloris, razvoj morfološke zgradbe mesta in njegove različne faze, avtor pa se ustavi tudi pri problematiki morfoloških območij, katerih določitev je pogosto končen rezultat preučevanja morfološke zgradbe mest.

Deseto poglavje je posvečeno socialnogeografski zgradbi mest. Mestno prebivalstvo je namreč nosilec razvoja mesta in poglavitni dejavnik njegove preobrazbe, zato se posamezni deli mesta po sestavi prebivalstva med sabo bistveno razlikujejo. Pozornost je namenjena tudi s tem povezanim problemom, npr. revščini v mestih in pojavom slumov. Posebne obravnave je deležna tudi etnična segregacija mestnega prebivalstva, ki je zlasti rezultat mednarodnih migracij prebivalstva. V okviru tega se avtor posveti etničnim območjem v mestih ZDA in etničnim območjem $v$ slovenskih mestih.

Tema enajstega poglavja sta gospodarstvo in funkcijska zgradba mest. Ta tematika je v sodobni urbani geografiji sicer nekoliko izgubila na pomenu, v začetnem obdobju razvoja urbane geografije pa je preučevanje gospodarskih dejavnosti v mestih predstavljalo eno njenih osrednjih vsebin. Avtor predstavi pojem mestnih funkcij, teorijo ekonomske osnove mest ter različne metode, ki so bile uporabljane v tem kontekstu. Obravnava tudi izrazito preobrazbo gospodarske strukture mesta, do katere je prišlo v zadnjih desetletjih, ter zgradbo mest.

Industrija je bila v obdobju industrializacije glavni dejavnik urbanizacije. Tako ni čudno, da je dvanajsto poglavje namenjeno ravno industriji $\mathrm{v}$ mestu ter novejšim procesom, povezanim z njo, npr. njeni selitvi na mestno obrobje ali celo zunaj urbanega območja. Naslednje poglavje se posveča storitvam in trgovini v mestu. Njihov gospodarski pomen je v mestih praviloma zelo velik, saj je na urbanih območjih delež zaposlenih v njih praviloma večji od polovice. Tudi trgovina je v zadnjih desetletjih doživela velike spremembe (npr. zamiranje trgovin v mestnih središčih ter razvoj nakupovalnih središč na mestnem obrobju), zato je tej tematiki namenjen največji del poglavja.

Posebno poglavje je namenjeno mestu in prometu, saj je promet velik porabnik mestnih površin, hkrati pa je neposredno povezan z razvojem mesta in njegovo strukturo. Avtor obravnava promet $\mathrm{v}$ mestih tudi kot vir različnih problemov - od prometnih zastojev do negativnih okoljskih učinkov. 
V poglavju, namenjenemu degradiranim urbanim območjem in urbani prenovi, avtor najprej na splošno predstavi obravnavano problematiko, potem pa se posveti degradiranim območjem v Sloveniji. V drugem delu poglavja je pozornost namenjena urbani revitalizaciji in prenovi, ki se je v osemdesetih letih dvajsetega stoletja uveljavila kot ena pomembnejših usmeritev $\mathrm{v}$ urbani prostorski politiki.

Za konec se avtor posveti še nekaterim specifikam urbanega razvoja, in sicer socialističnemu/postsocialističnemu mestu ter urbanizaciji v t.i. tretjem svetu. Specifične značilnosti mest in urbanizacije $v$ tretjem svetu so posledica drugačnega političnega, gospodarskega in socialnega razvoja in tem posebnostim je namenjen velik del poglavja, ki se zaključi s predstavitvijo sodobnih razvojnih procesov in problemov v mestih Latinske Amerike in Kitajske.

Knjiga Urbana geografija: geografske značilnosti mest in urbanizacije v svetu je rezultat dolgoletnega avtorjevega znanstvenoraziskovalnega in pedagoškega dela. Kot poudarja recenzent Mirko Pak, gre pri pričujoči knjigi za v Sloveniji doslej najbolj temeljit prikaz teoretskih izhodišč in metodoloških postopkov ter razvoja posameznih elementov urbane geografije. Delo predstavlja izčrpen in sistematičen pregled dogajanj in spoznanj s področja urbane geografije in tako lahko služi kot dragocen vir informacij tako strokovnjakom s področja geografije in sorodnih ved kot tudi vsem drugim, ki jih zanima problematika razvoja mest. Kot tako bo zanesljivo našlo širok krog bralcev in prispevalo tudi k večjemu zanimanju za to aktualno tematiko.

Dejan Cigale 